\title{
IFN- $\gamma$ Mediated Signaling Improves Fungal Clearance in Experimental Pulmonary Mucormycosis
}

\author{
Amanda Ribeiro dos Santos - Thais Fernanda Fraga-Silva • Débora de Fátima Almeida-Donanzam • \\ Rodolfo Ferreira dos Santos • Angela Carolina Finato • Cleverson Teixeira Soares • \\ Vanessa Soares Lara • Nara Lígia Martins Almeida • Maria Izilda Andrade • \\ Olavo Speranza de Arruda $\cdot$ Maria Sueli Parreira de Arruda $\cdot$ James Venturini (i)
}

Received: 29 March 2021 / Accepted: 13 October 2021 / Published online: 29 October 2021

(C) The Author(s), under exclusive licence to Springer Nature B.V. 2021

\begin{abstract}
We established three immunocompetent murine models of pulmonary mucormycosis to determine the involvement of the adaptive immune response in host resistance in pulmonary mucormycosis, a rapidly fatal disease caused mainly by Rhizopus spp. Immunocompetent inbred (C57BL/6, $\mathrm{BALB} / \mathrm{c}$ ) and outbred (Swiss) strains of mice were inoculated with $R$. oryzae via the intratracheal route. The inoculation resulted in a disseminated infection that spread to the brain, spleen, kidney, and liver. After 7 and 30 days of $R$. oryzae infection, BALB/c mice showed the lowest fungal load and highest production of IFN- $\gamma$ and IL- 2 by splenocytes. Swiss mice showed a higher fungal load 30 days p.i. and was associated
\end{abstract}

Handling Editor: Anamelia Lorenzetti Bocca.

Supplementary Information The online version contains supplementary material available at https://doi.org/10.1007/ s11046-021-00598-2.

A. R. dos Santos - D. de Fátima Almeida-Donanzam . R. F. dos Santos · A. C. Finato - O. S. de Arruda . M. S. P. de Arruda - J. Venturini $(\bowtie)$ Faculdade de Ciências, Universidade Estadual Paulista (Unesp), Bauru, SP 17033-360, Brazil e-mail: james.venturini@ufms.br

A. R. dos Santos - D. de Fátima Almeida-Donanzam · J. Venturini Faculdade de Medicina, Universidade Federal de Mato Grosso do Sul (UFMS), Cidade Universitária, Unit 9, Campo Grande, MS 79070-900, Brazil with a weak development of the Th-1 profile. To confirm our findings, R. oryzae-infected IFN- $\gamma^{-} /^{-}$ mice were evaluated after 60 days, where the mice still showed viable fungi in the lungs. This study showed, for the first time, that pulmonary mucormycosis in three widely used mouse strains resulted in an acute fungal dissemination without immunosuppression whose outcome varies according to the genetic background of the mice. We also identified the partial role of IFN- $\gamma$ in the efficient elimination of $R$. oryzae during pulmonary infection.

Keywords Fungal infection - Rhizopus oryzae . Swiss mice $\cdot \mathrm{BALB} / \mathrm{c}$ mice $\cdot \mathrm{C} 57 \mathrm{bl} / 6 \mathrm{mice} \cdot \mathrm{IFN}-\gamma^{-} /^{-}$ mice

\author{
T. F. Fraga-Silva \\ Departamento de Bioquimica e Imunologia, Universidade \\ de São Paulo, Escola de Medicina de Ribeirão Preto, \\ São Paulo, SP 14049-900, Brazil \\ C. T. Soares · M. I. Andrade \\ Lauro de Souza Lima Institute, Bauru, SP 17034-971, \\ Brazil \\ V. S. Lara · N. L. M. Almeida \\ Faculdade de Odontologia de Bauru (FOB), Universidade \\ de São Paulo (USP), Bauru, SP 17012-901, Brazil
}




\section{Introduction}

Mucormycosis is a severe fungal disease caused by various ubiquitous filamentous fungi of the order Mucorales, wherein Rhizopus spp. and Mucor spp. are the most prevalent causal agents [1]. During the COVID-19 pandemic, COVID-19-associated mucormycosis emerged at unprecedented rates throughout India and brought up as a threat around the world [2-5]. Although aspergillosis remains the most frequent opportunistic mold infection, mucormycosis is an important systemic mycosis due to its increased incidence and high lethality [6]. Pulmonary mucormycosis is a rapidly fatal illness that typically develops in patients with profound neutropenia and graft-versus-host disease [6, 7], with an overall mortality rate of $76 \%$, which increases to $95 \%$ after extrathoracic dissemination [8-14]. Combined surgi$\mathrm{cal} /$ medical treatment may provide a better survival outcome in pulmonary mucormycosis compared to medical therapy alone [15].

Despite the importance of fungus-host interactions in pulmonary mucormycosis, few studies have been conducted on this infection. In an experimental model of pulmonary mucormycosis, it was demonstrated that the inhibition of Rhizopus growth inside alveolar macrophages is a central host defense mechanism that depends on nutritional immunity via iron starvation [16]. In addition, the same study showed that although bronchoalveolar macrophages can inhibit the germination of $R$. oryzae spores, they are not capable of killing them $[16,17]$. It has been demonstrated that the inability of macrophages to kill Rhizopus sp. is due to the inhibition of LC3-associated phagocytosis (LAP), a specialized pathway of phagosome biogenesis that plays a central role in the regulation of immune homeostasis and antifungal host defense [16, 18, 19]. These early inhibition effects result in phagosome maturation arrest and account for resistance to macrophage killing [16]. However, several questions on the signaling pathways, cytokine responses, and activation of macrophages by the adaptive immune response remain unanswered.

Few studies have addressed the association of acquired $\mathrm{T}$ cell deficiency with increased susceptibility to infection by Mucorales [20]. However, investigators recently observed the presence of Mucoralesspecific $\mathrm{T}$ cells in patients with invasive mucormycosis [21]. In addition, immunotherapy strategies have been a promising tool for controlling mucormycosis since anti-Rhizopus $\mathrm{T}$ cells from healthy volunteers demonstrated reactivity against Mucorales and enhanced the phagocyte killing effect of Mucorales $[22,23]$. It has also been shown that IFN- $\gamma$ and granulocyte-macrophage colony-stimulating factor (GM-CSF) stimulated human polymorphonuclear leukocytes to augment hyphal damage in Rhizopus species [24], and immunotherapy in combination with IFN- $\gamma$ resulted in an effective treatment of a patient with intractable invasive mucormycosis [25].

In vitro and experimental studies suggest the protective role of the Th-17 type of adaptive immune response in the context of invasive mucormycosis, as well as the unprotective role of Th-2. It was shown that the hyphae of Rhizopus oryzae triggered a common innate sensing pathway in human dendritic cells, resulting in the robust production of IL-23 and Th-17 responses [26]. Indeed, the important role of the Th-17 response in disseminated mucormycosis was recently confirmed by our group. IL- $17^{-/-}$mice are susceptible to intravenous $R$. oryzae infection. In addition, more efficient fungal clearance in immunocompetent models of disseminated mucormycosis was associated with IL-17, while less efficient elimination of $R$. oryzae was associated with increased levels of IL-10 [27].

Taken together, the in vitro and experimental studies in mucormycosis seem to be consistent with that of human disease and collaborate with the improvement of current therapies for invasive mucormycosis. However, studies investigating the adaptive immune response, specifically in the context of pulmonary mucormycosis, have been rarely investigated. Considering this lack of knowledge, we established a murine model of pulmonary mucormycosis to study the adaptive immune response related to resistance during $R$. oryzae pulmonary infection.

\section{Materials and Methods}

Mice

Female BALB/c (inbred) and Swiss (outbred) mice were purchased from the Lauro de Souza Lima Institute (ILSL), Bauru, SP, Brazil. Wild type C57BL/6 (inbred-WT) and IFN- $\gamma$-deficient C57BL/6 mice $\left(\mathrm{IFN}-\gamma^{-} /^{-}\right), 6-10$ weeks old, were bred in a specific pathogen-free animal facility at the School of 
Medicine of Ribeirao Preto, University of São Paulo, Brazil. The genotypes of these knockout mice (IFN$\gamma^{-} /^{-}$mice) were determined using a previously established polymerase chain reaction technique [28]. All mice were maintained in the animal facilities at the Experimental Immunopathology Laboratory (LIPE), UNESP — Univ. Estadual Paulista, Bauru, SP, Brazil. Food and sterile water were provided ad libitum. All protocols used were in accordance with the ethical principles for animal research adopted from the National Council for Animal Experimentation Control (CONCEA). The Ethical Committee of the School of Science, UNESP, Bauru, SP, Brazil approved this study (\#1608/46/01/2013).

\section{Fungal Strains}

$R$. oryzae (IAL 3796) was originally obtained from the fungal collection of ILSL, and species identification was confirmed by the Adolfo Lutz Institute (São Paulo, SP, Brazil). The fungi were maintained through monthly subculturing on Sabouraud dextrose agar (SDA) slants (Difco Laboratories Detroit, Michigan, USA).

\section{Experimental Design}

Groups of 6-7 R. oryzae-infected BALB/c, Swiss, and C57BL/6 mice were evaluated on $24 \mathrm{~h}, 7$ and 30 days post-inoculation (p.i.). The IFN- $\gamma$ KO group was composed of $R$. oryzae-infected mice that were followed up for 60 days. The control groups were composed of mice subjected to the same procedures but inoculated with sterile saline solution (SSS).

\section{Fungal Infection}

Fungi were washed carefully with SSS, and the suspensions were vortexed twice for $10 \mathrm{~s}$ and decanted off for $5 \mathrm{~min}$. The supernatants were collected and washed twice with SSS. Fungal viability was determined using cotton blue staining and plating of the suspension on SDA plates. For the intratracheal inoculation, mice were anesthetized via intraperitoneal administration of ketamine and xylazine at doses of 80 and $10 \mathrm{mg} / \mathrm{kg}$ body weight, respectively. After tracheal exposition, each mouse was inoculated with $2 \times 10^{6}$ Rhizopus oryzae spores in $40-\mu \mathrm{L}$ of the suspension. The incision was sutured with surgical thread, and the animals were kept in a warm place and observed for recovery.

\section{Collection of Biological Materials}

Mice were anesthetized with isoflurane and then euthanized via $\mathrm{CO}_{2}$ asphyxiation. Fragments of the brain, liver, lung, spleen, kidneys, and thymus were collected and subjected to microbiological and histopathological analyses. Fragments of the spleen were also subjected to cell culture procedures.

\section{Recovery of Viable Fungi}

Ten fragments $(2 \times 2 \mathrm{~mm})$ of the brain, liver, lung, spleen, and kidneys were cultured on SDA plates at $25{ }^{\circ} \mathrm{C}$ for 7 days [27, 29]. Fungal growth on the fragments were counted, and the results were expressed as the frequency of $R$. oryzae-positive fragments per total number of cultivated fragments. Preliminary experiments confirmed that homogenization of tissues from $R$. oryzae-infected mice failed to recover viable fungi.

\section{Spleen Cell Culture}

The spleen fragments were collected and homogenized in ice-cold sterile PBS. Red blood cells were lysed with $0.15 \mathrm{M}$ ammonium nitrate. After washing, the cellular suspension was adjusted to $2.0 \times 10^{6}$ cells per $\mathrm{mL}$ as determined by $0.1 \%$ trypan blue staining. A total of $2.0 \times 10^{5}$ spleen cells were placed into each well of 48 -well flat-bottom microtiter plates and incubated at $37{ }^{\circ} \mathrm{C}$ in a $5 \% \mathrm{CO}_{2}$ humidified chamber. The cells were cultured or not with heat-killed spores of Rhizopus ( 1 spore: 1 cell) and after $48 \mathrm{~h}$, the cellfree supernatants were harvested and stored at $-80{ }^{\circ} \mathrm{C}$ for cytokine analysis.

\section{Cytokine Production}

Levels of IFN- $\gamma$, IL-2, IL-17, and IL-4 were measured in the cell-free supernatants of the cell cultures using a cytokine Duo-Set Kit (R\&D Systems, Minneapolis, USA), according to the manufacturer's instructions. 
Histopathological Score Analyses

Tissue fragments were fixed in $10 \%$ neutral-buffered formalin. Paraffin slides $(4 \mu \mathrm{m})$ were stained with hematoxylin and eosin (H\&E). Microscopic examination was carried out using an optical light microscope coupled to a camera (Zeiss ${ }^{\circledR}$, Jena, Germany), under $10 \times$ and $40 \times$ magnifications, throughout the length of the cut, and involved qualitative and semi-quantitative analyses of the organs. In the qualitative analyses, the following parameters were observed: presence/absence of (a) hyphae and spores, (b) tissue and cell damage, (c) vascular alteration, and (d) inflammatory cell infiltrates. The semi-quantitative analyses were based on the scores for inflammatory infiltrates, assigning the following subjective scores according to the intensity of the inflammatory cells: (0) absence, (1) mild, (2) moderate, and (3) severe. Representative images of qualitative microscopic alterations were captured and recorded for comparison between the different lineages.

\section{Statistical Analyses}

Comparison of two independent samples was performed using the $t$-test, and multiple comparisons of three independent samples were performed using ANOVA with the Tukey post-test. All statistical tests were performed using GraphPad Prism (version 5.0) for Windows (GraphPad Software, San Diego, CA), and the statistical significance level was set at 5\% $(p \leq 0.05)$ for all analyses.

\section{Results}

Development of the Intratracheal R. oryzae Infection in Immunocompetent Mice

In pulmonary mucormycosis, the infection occurs through inhalation of sporangiospores, causing pulmonary infection [30], and can spread contiguously into other internal organs, such as the abdomen, increasing the mortality rate from 76 to $95 \%$ in immunocompromised patients [8-14]. In order to investigate whether $R$. oryzae pulmonary infection induces sustained dissemination in immunocompetent mice, we infected three strains of mice via the intratracheal route and evaluated the mice after $24 \mathrm{~h}$, 7 and 30 days, first evaluating disease progression via recuperation of viable fungi and histopathological analyses.

After 7 days of $R$. oryzae intratracheal inoculation, all mice showed viable fungi in the brain, kidney, liver, lung, and spleen (Table 1). After 30 days, $\mathrm{BALB} / \mathrm{c}$ mice showed a reduction in fungal load in all evaluated tissues. C57BL/6 mice showed reduced recovery of viable fungi in the brain and Swiss mice showed reduced fungal loads in the liver and lungs after 30 days p.i. (Table 1). Comparison of the total fungal load among mouse strains showed that BALB/c mice showed the highest fungal load after 7 days of infection, and after 30 days, BALB/c mice showed the lowest fungal load among the three strains (Table 1).

Next, we performed qualitative and semi-quantitative analyses of the histopathological patterns of infection in the brain, kidneys, liver, and lungs. In the semi-quantitative analyses, we observed that the infiltrate scores did not differ among the strains (Fig. 1). In the qualitative analyses, the pattern of tissue changes did not differ among the strains. In order to find fungal structures in the lung after intratracheal inoculation and illustrate the angioinvasion, we analyzed lung sections of mice after $24 \mathrm{~h}$ of infection and observed intensive mixed inflammatory infiltrates specifically neutrophils and mononuclear cells in perivascular, peribronchial and in alveolar septa region with $R$. oryzae spore presence in tissue and inside the blood vessel. In addition, emphysema, hyperemic vessels, and damage of airway epithelial cells were also observed (Fig. 2). In general, our qualitative analyses revealed that after 7 and 30 days p.i., the inflammatory infiltrate in the lung became more diffuse and less intense respectively, with predominance of mononuclear cells (Supplementary information 1). After 7 and 30 days of infection, microhemorrhage and inflammatory infiltrate especially in the foci, were observed mainly perivascular and near the meninges of the brain (Fig. 3). In the kidney, the lesions were observed to have foci of inflammatory cells in the cortex, and diffuse inflammatory cell infiltration in the medulla, hyperemic 
Table 1 R. oryzae dissemination after intratracheal infection in three mouse strains

\begin{tabular}{llcccc}
\hline \multirow{2}{*}{ Brain } & Stage of infection & BALB/c & C57BL/6 & Swiss & $P$ value \\
& 7 days & 72.00 & 48.00 & 36.00 & 0.4019 \\
& 30 days & 0.020 & 0.0020 & 4.000 & 0.3984 \\
Kidney & $P$ value & $0.0007^{*}$ & $0.0322^{*}$ & 0.1950 & \\
& 7 days & 64.00 & 24.00 & 24.00 & 0.2684 \\
& 30 days & 0.020 & 5.00 & 15.00 & 0.5345 \\
Liver & $P$ value & $0.0082^{*}$ & 0.4248 & 0.7231 & \\
& 7 days & 68.00 & 32.00 & 52.00 & 0.2330 \\
Lung & 30 days & 4.000 & 20.00 & 12.00 & 0.6789 \\
& $P$ value & $0.0019^{*}$ & 0.6329 & $0.0462^{*}$ & \\
Spleen & 7 days & $100.0^{\mathbf{A}}$ & $53.00^{\mathbf{B}}$ & $96.00^{\mathbf{A B}}$ & $0.0295^{\#}$ \\
& 30 days & 28.33 & 15.00 & 44.00 & 0.4118 \\
& $P$ value & $0.0002^{*}$ & 0.1637 & $0.0303^{*}$ & \\
Total fungal load & 7 days & $80.00^{\mathbf{A}}$ & $8.00^{\mathbf{B}}$ & $60.40^{\mathbf{A}}$ & $0.0015^{\#}$ \\
& 30 days & 0.020 & 25.00 & 32.00 & 0.2703 \\
& $P$ value & $0.0002^{*}$ & 0.3645 & 0.2277 & \\
& 30 days & $76.80^{\mathbf{A}}$ & $33.00^{\mathbf{B}}$ & $53.68^{\mathbf{A B}}$ & $0.0043^{\#}$ \\
& $P$ value & $6.333^{\mathbf{B}}$ & $14.00^{\mathbf{A B}}$ & $24.60^{\mathbf{A}}$ & $0.0207^{\#}$ \\
& & $0.0001^{*}$ & 0.1106 & $0.0152^{*}$ & \\
\hline
\end{tabular}

7 days p.i.

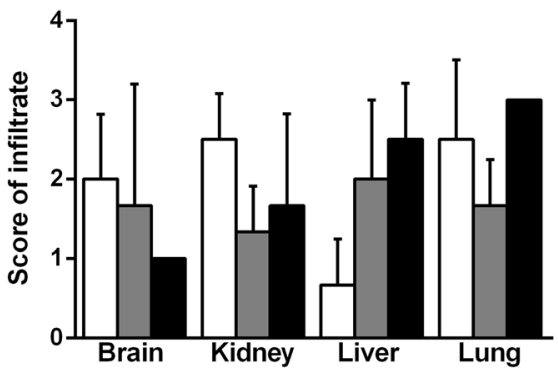

Fig. 1 Score of infiltrates in H\&E stained sections of organs after intratracheally $\mathrm{R}$. oryzae infection in immunocompetent mice strains. BALB/c, C57BL/6, and Swiss mice were infected intratracheally with $40 \mu \mathrm{L}$ of a solution containing $2 \times 10^{6}$ spores of $R$. oryzae and after 7 and 30 days, fragments of organs such as the brain, kidneys, liver, and lungs were collected and

vessels, microhemorrhage, glomerular hypercellularity, and Bowman's capsular space loss/decrease in mice of the three strains of mice on days 7 and 30 p.i. (Fig. 4). In the liver, steatosis was observed after $24 \mathrm{~h}$ of infection and congested and dilated blood vessels and perivascular infiltration of inflammatory cells were observed in all three strains after 7 and 30 days p.i. (Fig. 5). No fungal structures were observed in sections of the brain, kidney or liver.
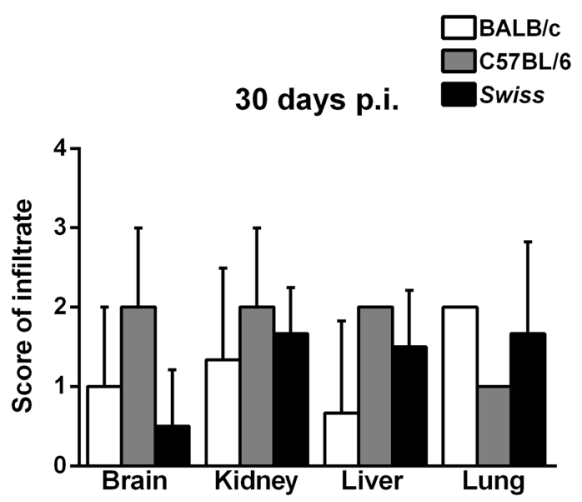

submitted to histopathological analysis. a) Comparison of inflammatory cells infiltrate score among BALB/c, C57BL/6, and Swiss strains after 7 days p.i. and, b) after 30 days p.i. Graphs show means with standard deviations. ANOVA with post-hoc Tukey test; $n=5$

\section{Cytokine Variation Profile Following R. oryzae Infection}

As observed in the comparison of the total fungal load, BALB/c mice showed the lowest fungal load while Swiss mice showed the highest fungal load among the three strains after 30 days of infection (Fig. 6a). In addition, $\mathrm{BALB} / \mathrm{c}$ mice were the most efficient strain in promoting fungal clearance in the lung after 30 days 
Fig. 2 Microscopic alterations in histological sections of the lung after intratracheally $\mathrm{R}$. oryzae infection in

immunocompetent mice strains. BALB/c, C57BL/6, and Swiss mice were infected intratracheally with $40 \mu \mathrm{L}$ of a solution containing $2 \times 10^{6}$ spores of $R$. oryzae and after 24 h, 7 and 30 days. Microscopic alterations evaluation was made by optical light microscopy, at $40 \times$ magnification, in 3 microscopic sections of the lung stained with Hematoxylin/Eosin (H\&E). Below are representative images of the different microscopic changes. a noninfected mice (Ctrl);

b mixed inflammatory infiltrates in perivascular, peribronchial and in alveolar septa region; and discrete enlargement of the alveolar spaces suggestive of emphysema in mice after $24 \mathrm{~h}$ of infection; c congested and hyperemic blood vessel; d damage airway epithelial cells-in the lower left corner $100 \times$ magnification; $\mathbf{e}-$ g inflammatory cell infiltration (neutrophils and mononuclear cells) in alveolar septa with $R$. oryzae spore and germling presence (black arrows)- in the lower left corner

$100 \times$ magnification; $\mathbf{h}-$ i neutrophils and $R$. oryzae spore (black arrow) inside the blood vessel suggestive of angioinvasion
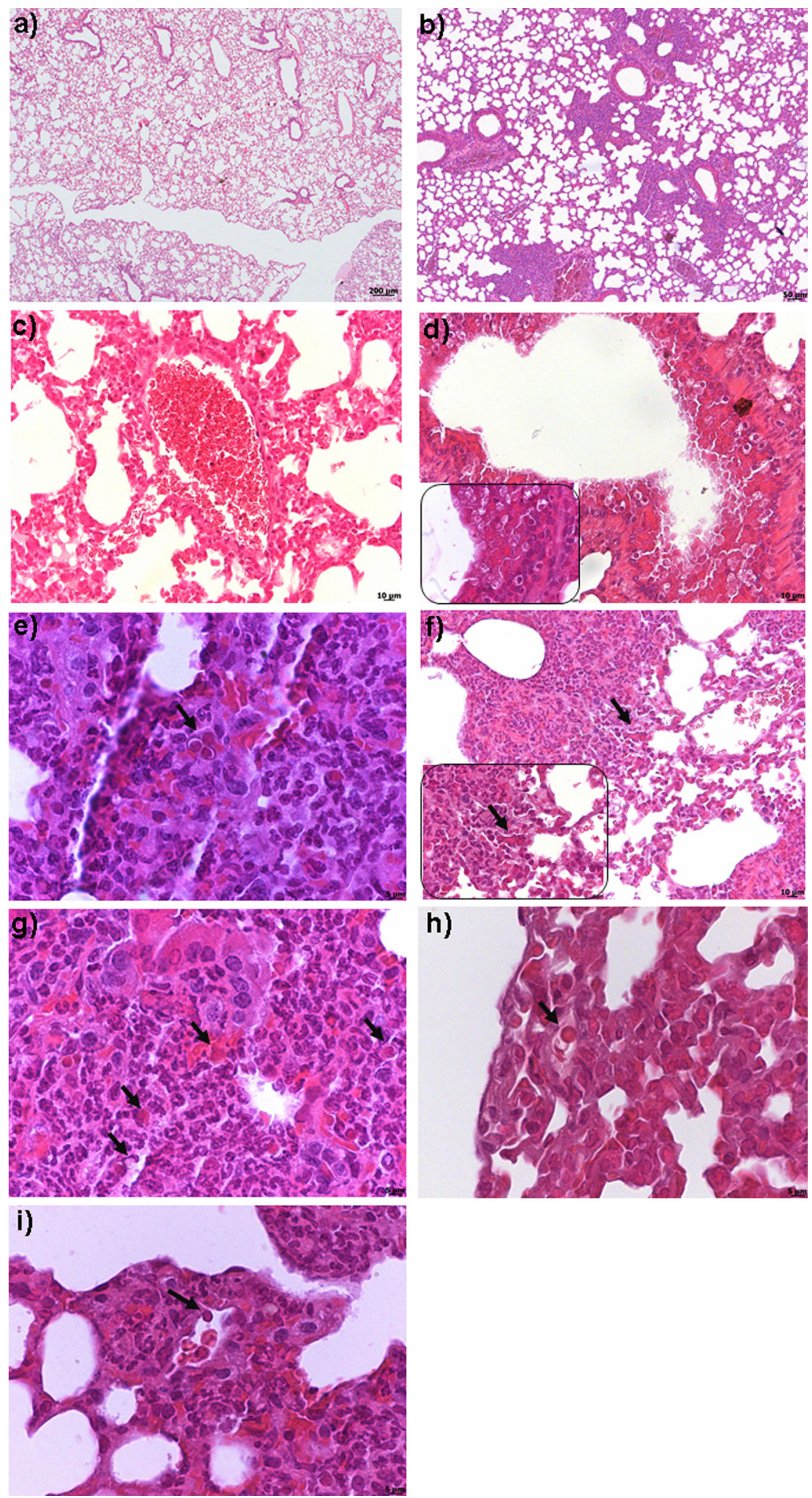

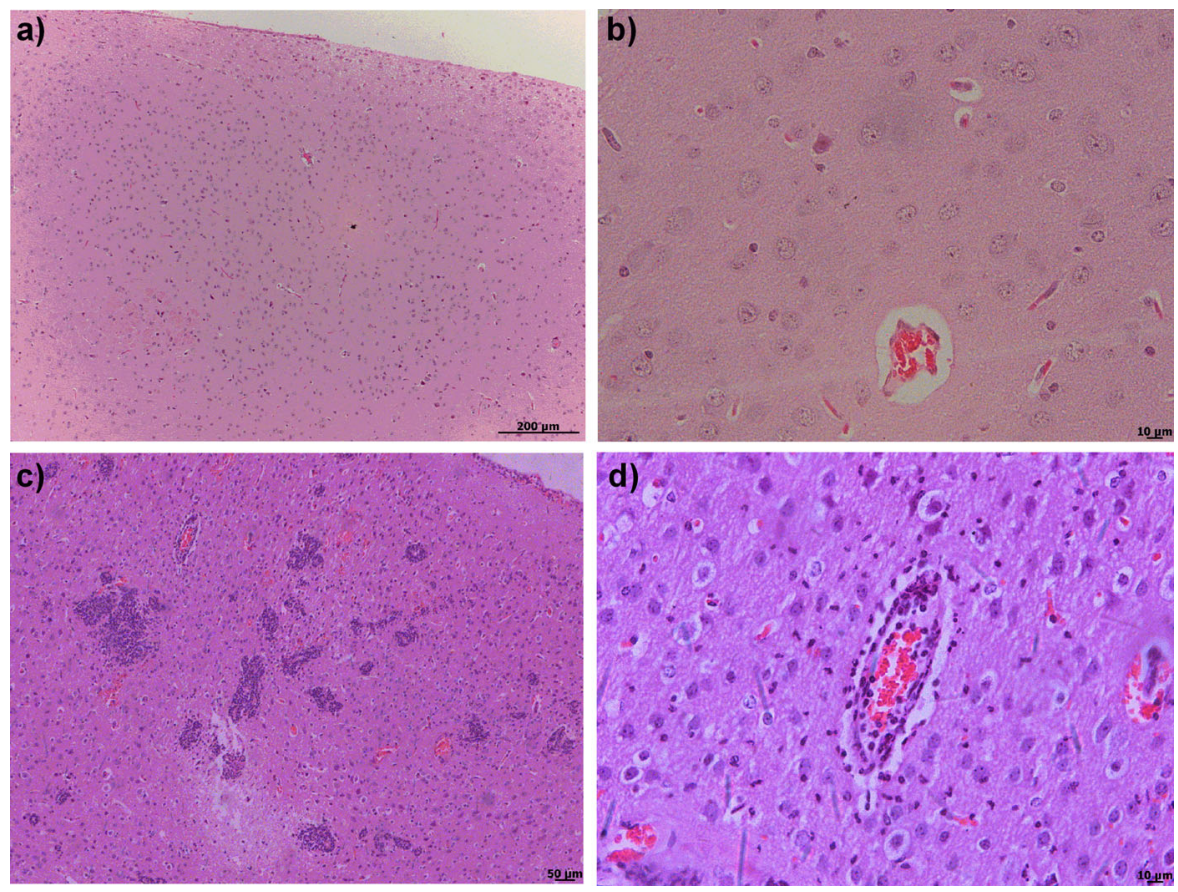

Fig. 3 Microscopic alterations in histological sections of the brain after intratracheally $\mathrm{R}$. oryzae infection in immunocompetent mice strains. BALB/c, C57BL/6, and Swiss mice were infected intratracheally with $40 \mu \mathrm{L}$ of a solution containing $2 \times 10^{6}$ spores of $R$. oryzae and after 24 h, 7 and 30 days. Microscopic alterations evaluation was made by optical light

microscopy, at $40 \times$ magnification, in 3 microscopic sections of the brain stained with Hematoxylin/Eosin (H\&E). Below are representative images of the different microscopic changes. ab non-infected mice (Ctrl); c microhemorrhage and focal inflammatory infiltrates in mice after 7 days of infection; d perivascular inflammatory infiltrate and hyperemic vessels
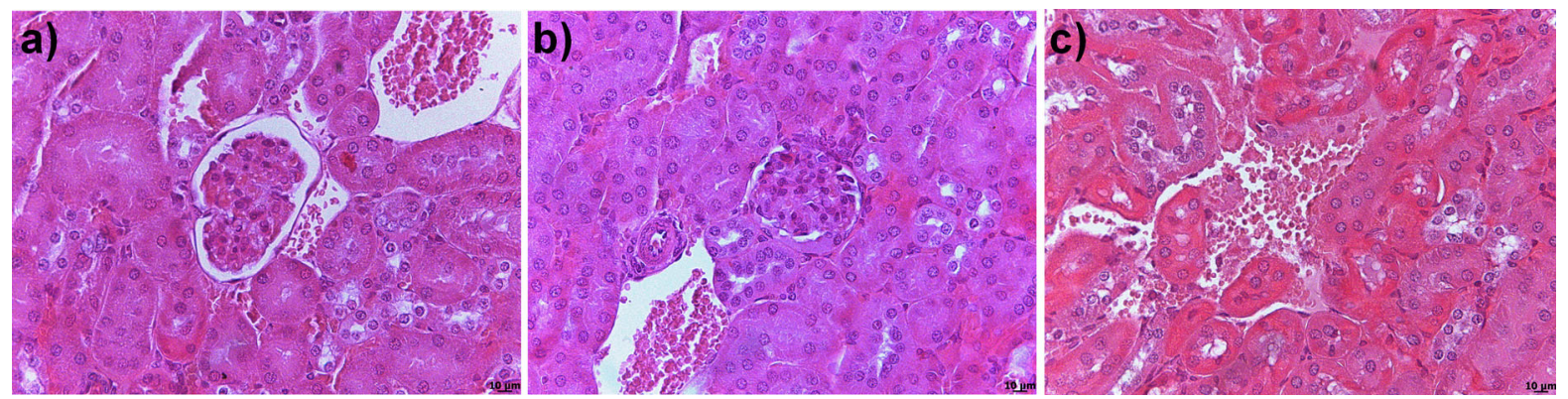

Fig. 4 Microscopic alterations in histological sections of the kidney after intratracheally R. oryzae infection in immunocompetent mice strains. BALB/c, C57BL/6, and Swiss mice were infected intratracheally with $40 \mu \mathrm{L}$ of a solution containing $2 \times 10^{6}$ spores of $R$. oryzae and after 24 h, 7 and 30 days. Microscopic alterations evaluation was made by optical light

of infection (Fig. 6b). Considering the different capacities of the mice to eliminate their fungal load until 30 days p.i., we next characterized their specific immune responses by analyzing the in vitro production of cytokines by spleen cells from infected or noninfected mice co-cultivated or not with $R$. oryzae. microscopy, at $40 \times$ magnification, in 3 microscopic sections of the kidney stained with Hematoxylin/Eosin (H\&E). Below are representative images of the different microscopic changes. a non-infected mice (Ctrl); b hyperemic vessels, glomerular hypercellularity and Bowman's capsular space loss/decrease in mice after 7 days of infection; $\mathbf{c}$ microhemorrhage

After 7 days of infection, increased production of IL-2 (Fig. 6c) and IFN- $\gamma$ (Fig. 6e), and decreased production of IL-17 (Fig. 6g) by non-stimulated spleen cells from $\mathrm{BALB} / \mathrm{c}$ mice were observed; whereas decreased production of IL-2 (Fig. 6c) and IFN- $\gamma$ (Fig. 6e) levels by non-stimulated spleen cells 

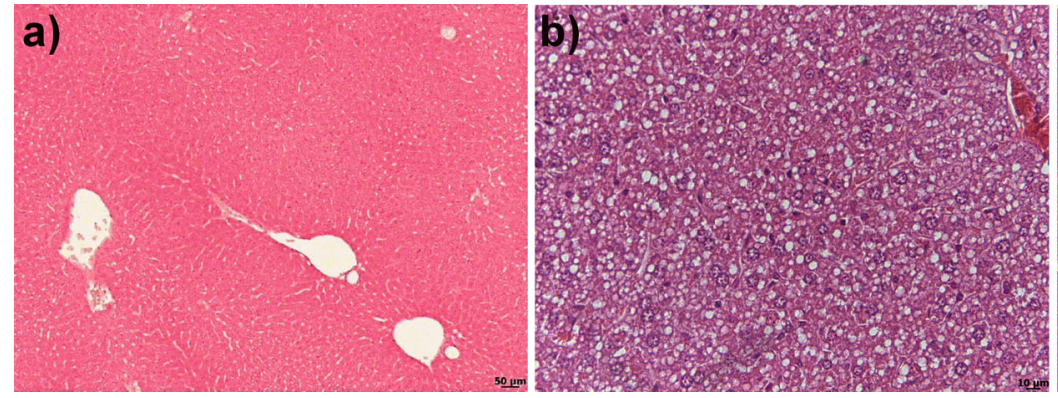

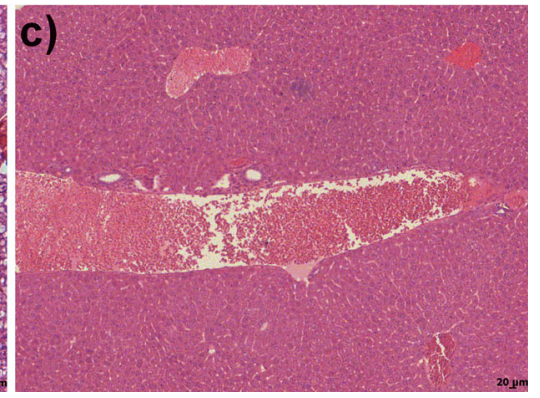

Fig. 5 Microscopic alterations in histological sections of the liver after intratracheally R. oryzae infection in immunocompetent mice strains. BALB/c, C57BL/6, and Swiss mice were infected intratracheally with $40 \mu \mathrm{L}$ of a solution containing $2 \times 10^{6}$ spores of $R$. oryzae and after 24 h, 7 and 30 days. Microscopic alterations evaluation was made by optical light

from Swiss mice were observed. After 30 days of infection, the production of IL-2 (Fig. 6c) and IFN- $\gamma$ (Fig. 6e) decreased, and the production of IL-17 increased by non-stimulated spleen cells from $\mathrm{BALB} / \mathrm{c}$ mice compared with 7 days p.i.; whereas increased production of IL-2 (Fig. 6c) and IFN- $\gamma$ (Fig. 6e) by non-stimulated spleen cells from Swiss mice compared with 7 days p.i were observed. Production of IL-2 (Fig. 6c), IFN- $\gamma$, and IL-17 by non-stimulated spleen cells from C57BL/6 mice did not change after the infection (Fig. 6). In addition, considering the differences in the production of cytokines by non-stimulated spleen cells among the three strains of mice, the spleen cells from Swiss mice showed the highest IFN- $\gamma$ (Fig. 2E) levels among the non-infected mouse strains. On the other hand, after 7 days of infection BALB/c mice showed higher IL-2 (Fig. 2C) and IFN- $\gamma$ (Fig. 2E) levels than C57BL/6 and Swiss mice; whereas Swiss mice showed lower IFN- $\gamma$ (Fig. 2E) levels than C57BL/6 and BALB/c. After 30 days of infection, the Swiss mice showed the highest IL-2 (Fig. 2C) level followed by BALB/c and C57BL/6 mice.

After 7 days of infection, increased production of IL-2 (Fig. 6d) by heat-killed $R$. oryzae-stimulated spleen cells from BALB/c and C57BL/6 mice was observed; whereas IFN- $\gamma$ (Fig. 6h) and IL-17 (Fig. 6h) levels did not change (Fig. 6a). In Swiss mice, decreased production of IL-17 (Fig. 6a) by heat-killed $R$. oryzae-stimulated spleen cells were observed; whereas IL-2 (Fig. 6d) and IFN- $\gamma$ (Fig. 6f) levels did not change. After 30 days of infection, the production of IL-2 (Fig. 6d) remained elevated by heat-killed $R$. microscopy, at $40 \times$ magnification, in 3 microscopic sections of the liver stained with Hematoxylin/Eosin (H\&E). Below are representative images of the different microscopic changes. a non-infected mice (Ctrl); b macrovesicular steatosis in mice $24 \mathrm{~h}$ post infection; $\mathbf{c}$ hyperemic vessels in mice after 7 days of infection

oryzae-stimulated spleen cells from $\mathrm{BALB} / \mathrm{c}$ and C57BL/6 mice than non-infected mice, and the production of IFN- $\gamma$ (Fig. 6f) and IL-17(Fig. 6h) remained with no significant changes by heat-killed $R$. oryzae-stimulated spleen cells from these two strains of infected mice. In Swiss mice, the production of IL-17 increased by heat-killed $R$. oryzae-stimulated spleen cells compared with 7 days p.i.; whereas levels of IL-2 (Fig. 6d) and IFN- $\gamma$ (Fig. 6f) did not change. About the differences in the production of cytokines by heat-killed $R$. oryzae-stimulated spleen cells from the three strains of mice, the spleen cells from Swiss mice showed the highest IL-2 (Fig. 6d) levels among the strains of non-infected mice. In addition, after 30 days of infection, heat-killed $R$. oryzae-stimulated spleen cells from Swiss mice showed the highest IL-2 (Fig. 6d) levels among the strains. In addition, heatkilled $R$. oryzae-stimulated spleen cells from Swiss and C57BL/6 mice showed higher levels of IL-17 (Fig. 6h) than BALB/c mice.

\section{R. oryzae Infection in IFN- $\gamma$ KO Mice}

Considering the association between fungal clearance and increased production of IFN- $\gamma$, we next investigated the role of IFN- $\gamma$ in IFN- $\gamma$ KO mice infected with $R$. oryzae. As shown in Fig. 7, the absence of IFN- $\gamma$ did not influence the survival of infected mice (Fig. 7a), but IFN- $\gamma$ KO mice showed a higher fungal load in the lungs than WT mice after 60 days of infection (Fig. 7b). 


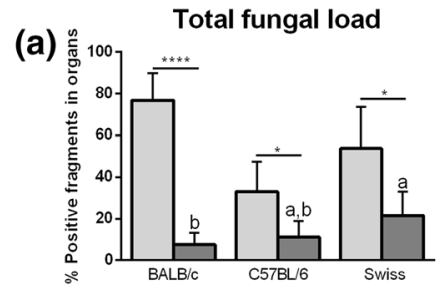

(c)

\section{Unestimulated spleen cells}

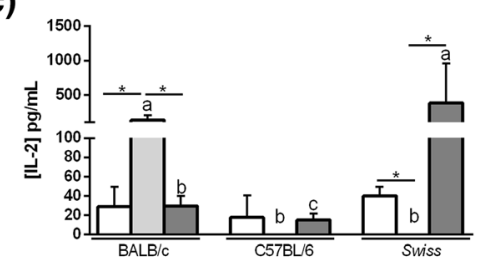

(e)

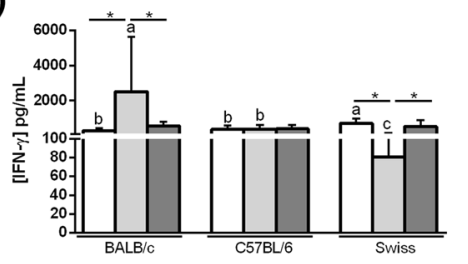

(g)

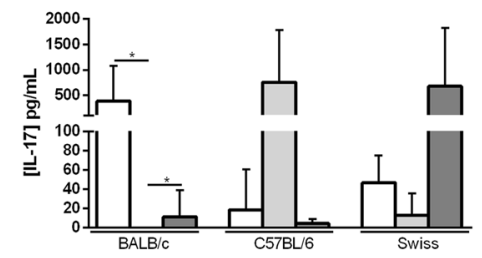

Fig. 6 Response of spleen cells after intratracheally $R$. oryzae infection in immunocompetent mice strains. BALB/c, C57BL/6, and Swiss mice were infected intratracheally with $40 \mu \mathrm{L}$ of a solution containing $2 \times 10^{6}$ spores of $R$. oryzae and were evaluated after 7 and 30 days. Fragments of brain, kidneys, liver, lung, and spleen were collected and evaluated by (a) total fungal load, (b) fungal load in lung and levels of cytokines in

\section{Discussion}

This study showed, for the first time, that experimental pulmonary mucormycosis in three widely used mouse strains resulted in fungal dissemination in the absence of immunosuppression. We also identified the partial role of IFN- $\gamma$ in the efficient elimination of $R$. oryzae during pulmonary infection (Fig. 8).

In mucormycosis, experimental models are widely used for the evaluation of antifungal therapy and, in these studies, immunosuppression is used to induce fungal dissemination in the murine models [31-34].

(d)

(f)

(h)

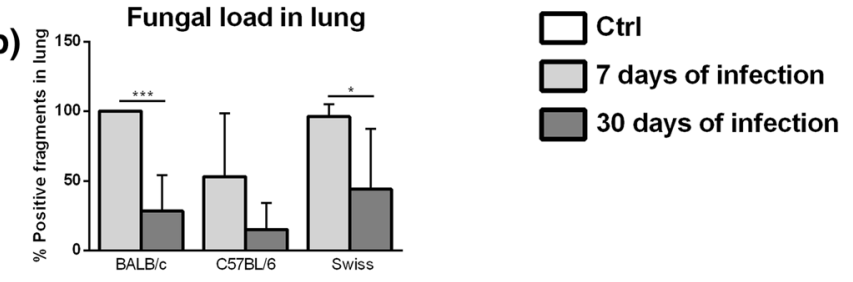

Heat-killed $R$. oryzae stimulated spleen cells
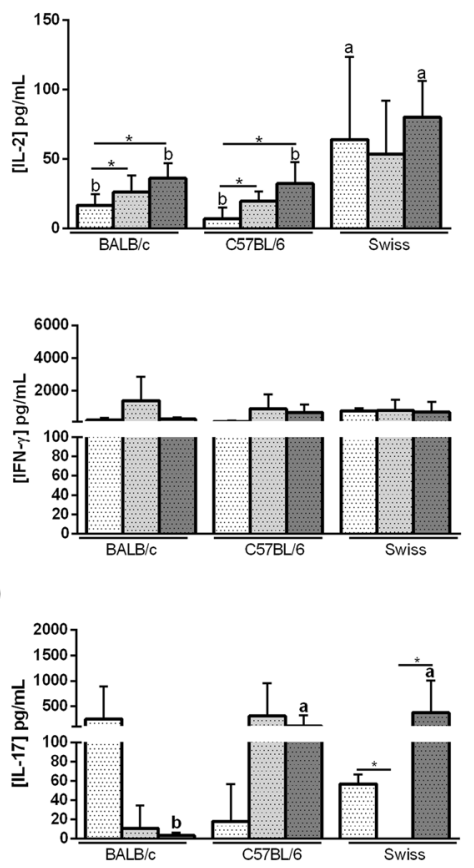

cell-free supernatant of spleen cells co-cultured or not with heatkilled spores of $R$. oryzae (c-h). Any significant differences relative to infected samples compared to different times post infection and to naive samples or to different strains (letters) are indicated. (ANOVA with post-hoc Tukey test; $n=5-7$; $* p<0.05, * * p<0.01, * * * p<0.001)$

Nevertheless, the effect of immunosuppressive drugs restricts the evaluation of the immunological mechanisms involved in fungal resistance. Recent studies exploring host-parasite relationships in mucormycosis have used immunocompetent models, such as disseminated mucormycosis models, using BALB/c, C57BL/ 6, and Swiss mice [27]; mucormycosis in a skin model using BALB/c mice [35]; and a pulmonary mucormycosis model using C57BL/6 mice [16]. Although pulmonary mucormycosis in immunocompetent C57BL/6 mice has been reported once [16], dissemination was not investigated, and the study focused on 


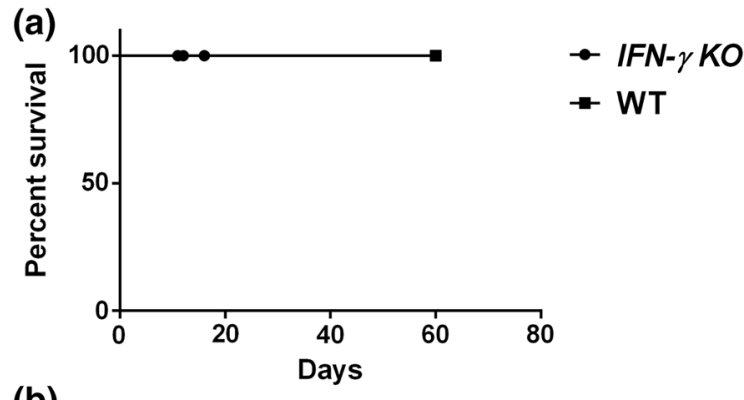

(b)

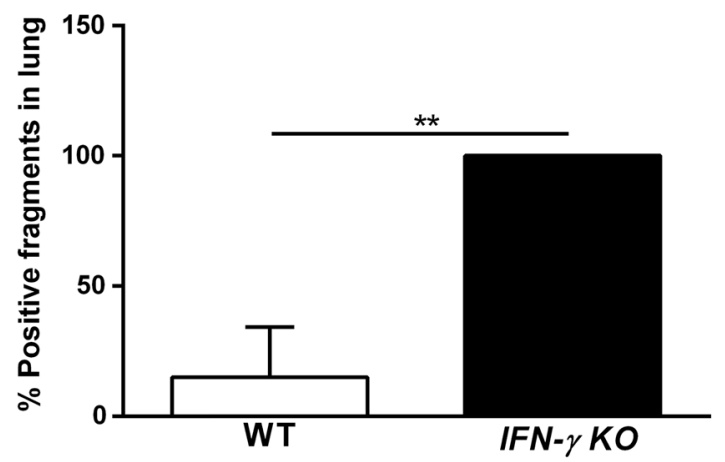

Fig. 7 Rhizopus oryzae infection in IFN- $\gamma^{-} /$mice. For IFN- $\gamma$ evaluation, IFN- $\gamma^{-} \digamma$ mice (mice of a C57BL/6 background with genetic-deficient IFN- $\gamma$ production) and WT (C57BL/6 mice) were infected intratracheally with $40 \mu \mathrm{L}$ of a solution containing $2 \times 10^{6}$ spores of $R$. oryzae and evaluated as follows: A mortality rate (Kaplan-Meier survival curves, $n=5$ ), B viable fungal recovery (ANOVA with post-hoc Tukey test; $n=5-7 ; * p<0.05$, ** $p<0.01, * * * p<0.001$; data were expressed as the percentage of $R$. oryzae-positive fragments out of the total fragments per group)

the innate immune response against $R$. oryzae, while the adaptive immune response in pulmonary infection is still unknown.

Considering this, our study was the first to characterize a model of a pulmonary infection of $R$. oryzae that induces dissemination in immunocompetent mice. Angioinvasion has been associated with the ability of the pathogen to disseminate hematogenously from the primary site of infection to other organs [36]. In humans, pulmonary mucormycosis occurs due to the inhalation of fungal spores into the bronchioles and alveoli, which typically results in the rapid progression of pneumonia or endobronchial disease, hemoptysis with vascular invasion causing necrosis, and invading tissue to spread locally or disseminate systemically [8].

In our histopathological analysis we observed that after $24 \mathrm{~h}$ of $R$. oryzae spores intratraqueal infection, fungal spores and germling were visualized in lung of mice accompanied of intense broncoalveolar and perivascular inflammatory cells infiltrate, and regions with airway epithelial cells damage. In this context, experimental and in vitro studies have been shown that once in alveolar space, Mucorales invade airway epithelial cells. It was seen that Rhizopus arrhizus var. delemar can recognize $\beta 1$ as a receptor on alveolar epithelial cells, causing the activation of epidermal growth factor receptor (EGFR), leading to host cell invasion, and consequently damage [37,38]. There are few studies characterizing the alveolar epithelial cells damage caused by Mucorales, and considering that lung epithelial cells are among the first host cells that interact with Mucorales spores during pulmonary infection, more studies are needed to better understand this point. After epithelial cell damage, the extracellular matrix proteins can be exposed for direct interaction with inhaled spores. It has been shown that $R$. oryzae spores have the ability to adhere to subendothelial matrix proteins including laminin and type IV collagen in vitro [39]. In addition, it is known that Rhizopus adheres to and invades endothelial cells by specific recognition of the host receptor glucoseregulator protein 78 (GRP78) [40, 41]. Although spores have ligands $(\mathrm{CotH})$ for GRP78 receptors on the epithelial cells, it has been recognized that germinated spores (germling) is the main form that invades the endothelial cells endocytosis. This recognition causes host cellular death by induction of the endothelial cell-mediated fungus endocytosis [42]. Besides, in the present study we find two spores: one apparently attached to endothelial cells and other in the blood vessel and no hyphae were visualized, indicating that in immunocompetent model, the hyphae invading form of Mucorales [42] can be less frequent or the differentiation is late. We suggest that more studies should be performed to clarify this finding.

Our $R$. oryzae-infected mice were characterized via the visualization of fungal spores in lung and vessels after $24 \mathrm{~h}$ of inoculation allied to recovery of viable fungal growth, hemorrhage, vessel alteration, and inflammatory cell infiltration in the lungs as well as in the brain, kidney, liver, and spleen after seven days of infection which suggest an angioinvasive infection, indicating that our models are similar to the human pattern of infection [43]. 


\section{Inoculation route}
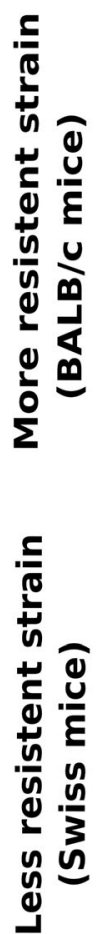

I.V. inoculation

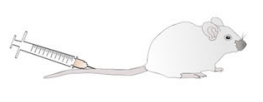

I.T. inoculation

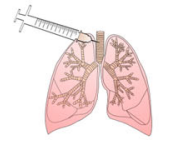

I.T. inoculation

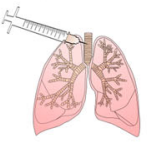

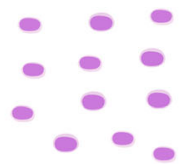

Spleen cell production in $R$. oryzae infected mice

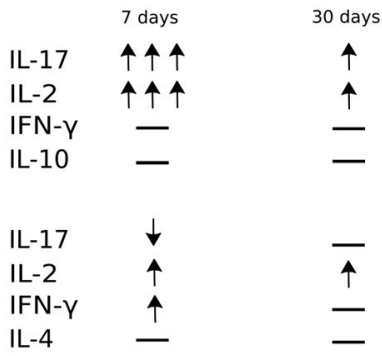

Low
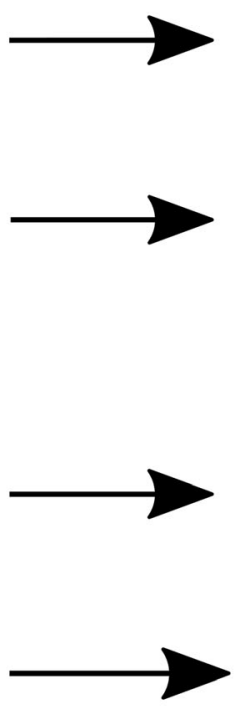

Fig. 8 Overview of immune response and fungal burden in $\mathrm{BALB} / \mathrm{c}$ and Swiss mice infected with $R$. oryzae via different routes of infection. BALB/c and Swiss mice were infected intravenously with $3 \times 10^{4}$ spores [27] or intratracheally with $2 \times 10^{6}$ spores of $R$. oryzae and evaluated after 7 and 30 days.

In a murine model of mucormycosis, angioinvasion was frequently observed following the establishment of pulmonary mucormycosis after intranasal challenge with Mucorales of corticosteroid-treated mice [44]. In the study above, it was observed that mice infected with up to $10^{6}$ spores of Lichtheimia corymbifera were susceptible to infection until 10 days p.i. [44]. In addition to the angioinvasion observed in our immunocompetent models of pulmonary mucormycosis, no fatality was observed in the mice after administration with an inoculum of $2 \times 10^{6}$ spores of $R$. oryzae. The lack of immunosuppression may explain the absence of susceptibility in our model; in addition, an intranasal inoculum of $2 \times 10^{6}$ spores of $R$. oryzae in BALB/c, C57BL/6, and Swiss immunocompetent mice did not lead to the recovery of viable

$\begin{array}{lcc} & 7 \text { days } & 30 \text { days } \\ \text { IL-17 } & - & \uparrow \\ \text { IL-2 } & - & \frac{\uparrow}{\text { IFN- }} \\ \text { IL-10 } & - & \uparrow \uparrow \\ \text { IL-17 } & \downarrow & \uparrow \\ \text { IL-2 } & \downarrow & \uparrow \\ \text { IFN- } & \downarrow & - \\ \text { IL-4 } & \downarrow & -\end{array}$

Cytokine concentrations were evaluated in cell-free supernatants from spleen cells co-cultured with heat-killed spores of $R$. oryzae. Summarized results of the fungal burden on day 30 are also shown

fungal or histological tissue alterations (data not shown). These data suggest that for the establishment of $R$. oryzae pulmonary infection in immunocompetent mice, intratracheal inoculation is more efficient than intranasal inoculation. Similar to our study, in C57BL/6 mice intratracheally infected with $R$. oryzae established as an immunocompetent model of pulmonary mucormycosis, considerable tissue edema, neutrophil infiltration, and viable $R$. oryzae in the lungs were observed five days p.i. [16]. In addition to the study above, we compared three different strains of mice and observed that differences in the capacity for fungal clearance was related to the genetic background.

It is well-established that inbred mouse strains have varying dynamics of infection. The differences in the 
type of immune response developed and the resulting severity of disease allows the applicability of mice with different genetic bases as effective tools for studying the dynamics of infections [45-48]. In this study, we observed that under pulmonary $R$. oryzae infection, inbred $(\mathrm{BALB} / \mathrm{c})$ mice strain was more resistant, while inbred (C57BL/6) and outbred (Swiss) mice were intermediary and less resistant strains respectively. Inbred lines of highly susceptible (A/J, A/Sn, DBA / 2) and highly resistant (BALB/c, C57BL/ $6 \mathrm{~J})$ mice have been described to be infected with Aspergillus fumigatus [35], Candida albicans [46], Cryptococcus neoformans [47], Paracoccidioides brasiliensis [38], and Rhizopus oryzae [27]. Some genetic targets such as C5-deficiency ( $\mathrm{Hc}^{\mathrm{O}}$ allele, hemolytic complement) and $\mathrm{C} 5$-independent pathways (such as the loci Carg3 and Carg4) have been identified to modulate the host's initial response and cause an ineffective inflammatory response against Candida albicans in some inbred mouse strains [46]. In Swiss mice, C5 deficiency is the cause of the high susceptibility to fungal infections [49-51]. In addition, in experimental models of disseminated mucormycosis, Swiss mice were the less resistant strain, compared with the other two inbred strains, showing an antiinflammatory response during intravenous $R$. oryzae infection.

Considering the lack of knowledge in the adaptive immune response in the context of pulmonary mucormycosis, in the present study we used the differences in response of three strains of mice against $R$. oryzae to identify relevant resistance mechanisms, and we observed that greater resistance against pulmonary infection was associated with an early Th-1 response mediated by higher IFN- $\gamma$ and IL-2 levels, as observed in the more resistant BALB/c strain while less resistance was associated with the decrease of IFN- $\gamma$ and IL-2 levels in Swiss strain. Although C57BL/6 and Swiss mice showed less efficiency in decreasing viable fungal than BALB/c mice mainly in lung, our results suggest that the infection control in these two strains of mice were mediated by a Th- 17 signaling, observed by increased production of IL-17 and IL- 2 by spleen. It is known that IFN- $\gamma$-producing Th- 1 cells confer protective immunity against fungi, whereas Th-2 responses increase susceptibility to fungal infections [52]. In addition, Th-17 cells have also been implicated in mucosal immunity against fungi [52]. IL-2 induces T cell clonal expansion and is a marker of adaptive immune response development [53].

In patients with invasive mucormycosis, Mucorales-specific T-cells showed high levels of IL-4, IFN$\gamma$, IL-10, and IL-17 [21]. In the same study, it was observed that all patients showed a high expression of IL-10 at the time of diagnosis and close to the time of their death. Interestingly, the absence of Mucoralesspecific $\mathrm{T}$ cells producing IL-10 was found in one patient at the time of complete resolution [21]. In addition, in an immunocompetent $\mathrm{BALB} / \mathrm{c}$ and C57BL/6 model of disseminated mucormycosis, resistance against $R$. oryzae was associated with higher levels of IL-17.

It has been noticed that different routes of inoculation may, at times, give rise to different host responses, which could be another explanation for the observed differences [54]. In this context, during intravenous inoculation of $C$. albicans, it was observed that Th-1 and Th-17 responses mediated protective adaptive immunity [45], while in experimental $C$. neoformans both intratracheal [56] and intravenous infection [57], a type of Th-1 response mediated by IFN- $\gamma$ was mainly developed. In aspergillosis, major T-helper cell lineages, Th-1, Th-2, and Th-17, have been demonstrated to play important roles in patients and animal models depending on the type of infection [58-62]. For invasive aspergillosis, the Th-17 type of response was essential for fungal control [63, 64], but in pulmonary infections caused by A. fumigatus, the Th-1 response profile is more effective [65]. In pulmonary infections, the Th-17 type of response seems to be pathogenic to the lung due to an uncontrolled or prolonged inflammatory response that caused persistent inflammation [66-68]. For mucormycosis, the pattern of adaptive immune response seems to be similar to that observed in aspergillosis. In disseminated mucormycosis, IL-17 signaling is crucial to control the infection and, as observed here in $R$. oryzae pulmonary infection, the Th-1 response was developed as evidenced by higher levels of IFN- $\gamma$ and was more effective for fungal control (Fig. 6).

It has been shown that the Th-1 response is crucial for fungal clearance since it potentiates the fungicidal activity of innate immune cells through IFN- $\gamma$ release [65, 69-71]. To elucidate the possible involvement of IFN- $\gamma$ signaling in the protection against $R$. oryzae pulmonary infection, we induced pulmonary 
mucormycosis in IFN- $\gamma^{-l-}$ mice and found that they were incapable of eliminating $R$. oryzae in the lungs until 60 days of infection. Indeed, the innate immune response during pulmonary mucormycosis was analyzed in other study from our group (Santos et al., in submission) and we have observed that after 7 days of pulmonary $R$. oryzae infection, alveolar macrophages from BALB/c mice showed higher levels of TNF-a and NO levels than alveolar macrophages from Swiss mice, and as observed here, this response resulted in a later control of infection. It is known that under influence of IFN- $\gamma$ the macrophages display functional subsets that are usually characterized by increased microbicidal activity as well as increased secretion of pro-inflammatory cytokines as $\mathrm{TNF} \alpha$ and reactive oxygen intermediates (ROI) and nitric oxide synthase2 (NOS-2/iNOS) [72]. Robust and timely production of nitric oxide (NO) by iNOS and analogous production of reactive oxygen species are critical components of an effective immune response [73]. Together with our results, these data indicate that, as observed in other fungal infections [55, 56, 65], the Th-1 response through IFN- $\gamma$ signaling is partially important for fungal clearance in mucormycosis [21, 31, 74, 75].

In contrast to our study, in an experimental model of invasive aspergillosis, the absence of IFN- $\gamma$ resulted in an increase in susceptibility to infection [76], while our IFN- $\gamma^{-1-}$ mice did not succumb to $R$. oryzae infection. Two hypotheses can explain these results. First, there was an absence of an immunosuppressive drug in our model to induce mucormycosis, while in the study above, a neutropenic model of mice induced to have invasive aspergillosis was used. Second, besides in this study the BALB/c mice showed better elimination of $R$. oryzae, the less resistant strain, Swiss mice, also controlled the infection through a late and increased IL-17 and IL-2 production. Not only IL-17 signaling [27], but also IL-2 have already shown to have a protective role in mucormycosis. For instance, IL-2 has already been demonstrated to be capable of activating human NK cells to damage $R$. oryzae hyphae, but it did not affect resting conidia in a previous in vitro study [23, 77].

Although responses other than Th- 1 are capable of preventing death in infected IFN- $\gamma^{-} /^{-}$mice, they were not as efficient as the response mediated by IFN- $\gamma$, since the IFN $-\gamma^{-} /^{-}$mice were unable to eliminate live $R$. oryzae conidia in the lungs and yet, the strain that better eliminated the fungal load in the lung was the unique strain of mice that developed Th-1 profile as main adaptive immune response against $R$. oryzae infection, the BALB/c mice. The absence of additional experiments to explore the mechanisms of survival of infected IFN- $\gamma^{-} /^{-}$mice and to confirm the complete role IFN- $\gamma$ in pulmonary mucormycosis were the main limitation of the present study, and we suggest that more studies should be done to clarify the survival mechanisms observed here.

In summary, we introduced three immunocompetent models of pulmonary $R$. oryzae infection resulting in angioinvasive mucormycosis, which permits new studies to explore infection dynamics in this context. Using the differences in capacity of murine models in eliminating $R$. oryzae, we gathered new insights into the immune response during pulmonary mucormycosis, and, in addition, we recognized that IFN- $\gamma$ contributes to a more effective mechanism of eliminating $R$. oryzae.

Acknowledgements This study was supported by FAPESP (Fundação de Amparo à Pesquisa do Estado de São Paulo), grant 2013/15513-3 for Amanda Ribeiro dos Santos.

Authors' Contributions Conceived of or designed study:OSA, MSPA, JV, VSL. Performed research:ARS, DFAD, RFS, ACF, CTS, VSL, NLMA, MIA. Analyzed data:ARS, TFFS, DFAD, NLMA, VSL, JV. Contributed new methods or models:VSL, NLMA.Wrote the paper:ARS, JV.

Funding This study was supported by FAPESP (Fundação de Amparo à Pesquisa do Estado de São Paulo) \# 2013/15513-3.

\section{Declarations}

Conflicts of interest The authors do not have a commercial or other association that might pose a conflict of interest.

Data Availability The authors confirm that the data supporting the findings of this study are available within the article.

\section{References}

1. Mendoza L, Vilela R, Voelz K, Ibrahim AS, Voigt K, Lee SC. Human Fungal Pathogens of Mucorales and Entomophthorales. Cold Spring Harb Perspect Med. 2014;5(4):a019562-a019562.

2. Mehta S, Pandey A. Rhino-Orbital Mucormycosis Associated With COVID-19. Cureus. 2020;12:e10726.

3. Revannavar SM, Supriya SP, Samaga L, Vineeth VK. COVID 19 triggering mucormycosis in a susceptible patient 
a new phenomenon in the developing world? BMJ Case Rep. 2021;14:e241663.

4. Sarkar S, Gokhale T, Choudhury SS, Deb AK. COVID-19 and orbital mucormycosis. Indian $\mathrm{J}$ Ophthalmol. 2021;69:1002-4.

5. Sen M, Lahane S, Lahane TP, Parekh R, Honavar SG. Mucor in a Viral Land: A Tale of Two Pathogens. Indian J Ophthalmol. 2021;69:244-52.

6. Roden MM, Zaoutis TE, Buchanan WL, Knudsen TA, Sarkisova TA, Schaufele RL, et al. Epidemiology and outcome of zygomycosis: a review of 929 reported cases. Clin Infect Dis Off Publ Infect Dis Soc Am. 2005;41:634-53.

7. Xhaard A, Lanternier F, Porcher R, Dannaoui E, Bergeron A, Clement L, et al. Mucormycosis after allogeneic haematopoietic stem cell transplantation: a French Multicentre Cohort Study (2003-2008). Clin Microbiol Infect Off Publ Eur Soc Clin Microbiol Infect Dis. 2012;18:E396-400.

8. Muqeetadnan M, Rahman A, Amer S, Nusrat S, Hassan S, Hashmi S. Pulmonary mucormycosis: an emerging infection. Case Rep Pulmonol. 2012;2012:120809.

9. Hamilos G, Samonis G, Kontoyiannis DP. Pulmonary mucormycosis. Semin Respir Crit Care Med. 2011;32:693-702.

10. Aboutanos MB, Joshi M, Scalea TM. Isolated pulmonary mucormycosis in a patient with multiple injuries: a case presentation and review of the literature. J Trauma. 2003;54:1016-9.

11. Agarwal R, Kumar V, Gupta D. Pulmonary mucormycosis: two of a kind. Eur J Intern Med. 2006;17:63-5.

12. Xia Z-K, Wang W-L, Yang R-Y. Slowly progressive cutaneous, rhinofacial, and pulmonary mucormycosis caused by Mucor irregularis in an immunocompetent woman. Clin Infect Dis Off Publ Infect Dis Soc Am. 2013;56:993-5.

13. Chacko B, David VG, Tamilarasi V, Deepti AN, John GT. Pulmonary mucormycosis in a nondiabetic renal allograft recipient successfully managed by medical therapy alone. Transplantation. 2007;83:1656-7.

14. Petrikkos G, Skiada A, Lortholary O, Roilides E, Walsh TJ, Kontoyiannis DP. Epidemiology and clinical manifestations of mucormycosis. Clin Infect Dis Off Publ Infect Dis Soc Am. 2012;54(Suppl 1):S23-34.

15. Hua-Ping Z, Jian L, Jing-Bin H, Jie G, Guo-Xin M, YanHong J, et al. Surgical resection and liposomal amphotericin B to treat cavitary pulmonary zygomycosis in a patient with diabetes. Respir Care. 2011;56:1837-9.

16. Andrianaki AM, Kyrmizi I, Thanopoulou K, Baldin C, Drakos E, Soliman SSM, et al. Iron restriction inside macrophages regulates pulmonary host defense against Rhizopus species. Nat Commun. 2018;9:3333.

17. Waldorf AR, Ruderman N, Diamond RD. Specific susceptibility to mucormycosis in murine diabetes and bronchoalveolar macrophage defense against Rhizopus. J Clin Invest. 1984;74:150-60.

18. Kyrmizi I, Gresnigt MS, Akoumianaki T, Samonis G, Sidiropoulos P, Boumpas D, et al. Corticosteroids Block Autophagy Protein Recruitment in Aspergillus fumigatus Phagosomes via Targeting Dectin-1/Syk Kinase Signaling. J Immunol Ame Assoc Immunol. 2013;191:1287-99.

19. Akoumianaki T, Kyrmizi I, Valsecchi I, Gresnigt MS, Samonis G, Drakos E, et al. Aspergillus Cell Wall Melanin
Blocks LC3-Associated Phagocytosis to Promote Pathogenicity. Cell Host Microbe. 2016;19:79-90.

20. Ibrahim AS, Kontoyiannis DP. Update on mucormycosis pathogenesis. Curr Opin Infect Dis. 2013;26:508-15.

21. Potenza L, Vallerini D, Barozzi P, Riva G, Forghieri F, Zanetti E, et al. Mucorales-specific T cells emerge in the course of invasive mucormycosis and may be used as a surrogate diagnostic marker in high-risk patients. Blood. 2011;118:5416-9.

22. Schmidt S, Tramsen L, Perkhofer S, Lass-Flörl C, Röger F, Schubert R, et al. Characterization of the Cellular Immune Responses to Rhizopus oryzae With Potential Impact on Immunotherapeutic Strategies in Hematopoietic Stem Cell Transplantation. J Infect Dis. 2012;206:135-9.

23. Castillo P, Wright KE, Kontoyiannis DP, Walsh T, Patel S, Chorvinsky E, et al. A New Method for Reactivating and Expanding T Cells Specific for Rhizopus oryzae. Mol Ther Methods Clin Dev. 2018;9:305-12.

24. Gil-Lamaignere C, Simitsopoulou M, Roilides E, Maloukou A, Winn RM, Walsh TJ. Interferon- $\gamma$ and GranulocyteMacrophage Colony-Stimulating Factor Augment the Activity of Polymorphonuclear Leukocytes against Medically Important Zygomycetes. J Infect Dis. 2005;191:1180-7.

25. Grimaldi D, Pradier O, Hotchkiss RS, Vincent J-L. Nivolumab plus interferon- $\gamma$ in the treatment of intractable mucormycosis. Lancet Infect Dis. 2017;17:18.

26. Chamilos G, Ganguly D, Lande R, Gregorio J, Meller S, Goldman WE, et al. Generation of IL-23 producing dendritic cells (DCs) by airborne fungi regulates fungal pathogenicity via the induction of $\mathrm{T}(\mathrm{H})-17$ responses. PloS One. 2010;5:e12955.

27. Santos AR dos, Fraga-Silva TF, F Almeida D de, dos Santos RF, Finato AC, Amorim BC, et al. Rhizopus-host interplay of disseminated mucormycosis in immunocompetent mice. Future Microbiol [Internet]. Future Medicine; 2020 [cited 2020 Jul 24]; Available from: https://www.futuremedicine.com/doi/https://doi.org/10.2217/fmb-20190246

28. Pfeffer K, Matsuyama T, Kündig TM, Wakeham A, Kishihara K, Shahinian A, et al. Mice deficient for the $55 \mathrm{kd}$ tumor necrosis factor receptor are resistant to endotoxic shock, yet succumb to L. monocytogenes infection. Cell. 1993;73:457-67.

29. Bagagli E, Sano A, Coelho KI, Alquati S, Miyaji M, de Camargo ZP, et al. Isolation of Paracoccidioides brasiliensis from armadillos (Dasypus noveminctus) captured in an endemic area of paracoccidioidomycosis. Am J Trop Med Hyg. 1998;58:505-12.

30. Cornely OA, Alastruey-Izquierdo A, Arenz D, Chen SCA, Dannaoui E, Hochhegger B, et al. Global guideline for the diagnosis and management of mucormycosis: an initiative of the European Confederation of Medical Mycology in cooperation with the Mycoses Study Group Education and Research Consortium. Lancet Infect Dis. 2019;19:e405-21.

31. Rodríguez MM, Pastor FJ, Calvo E, Salas V, Sutton DA, Guarro J. Correlation of in vitro activity, serum levels, and in vivo efficacy of posaconazole against Rhizopus microsporus in a murine disseminated infection. Antimicrob Agents Chemother. 2009;53:5022-5. 
32. Lewis RE, Albert ND, Liao G, Hou J, Prince RA, Kontoyiannis DP. Comparative pharmacodynamics of amphotericin B lipid complex and liposomal amphotericin B in a murine model of pulmonary mucormycosis. Antimicrob Agents Chemother. 2010;54:1298-304.

33. Lewis RE, Liao G, Wang W, Prince RA, Kontoyiannis DP. Voriconazole pre-exposure selects for breakthrough mucormycosis in a mixed model of Aspergillus fumigatusRhizopus oryzae pulmonary infection. Virulence. 2011;2:348-55.

34. Lewis RE, Ben-Ami R, Best L, Albert N, Walsh TJ, Kontoyiannis DP. Tacrolimus enhances the potency of posaconazole against Rhizopus oryzae in vitro and in an experimental model of mucormycosis. $\mathrm{J}$ Infect Dis. 2013;207:834-41.

35. Bao W, Jin L, Fu H, Shen Y, Lu G, Mei H, et al. Interleukin22 Mediates Early Host Defense against Rhizomucor pusilluscan Pathogens. PLoS ONE [Internet]. 2013 [cited 2019 Jul 18];8. Available from: https://www.ncbi.nlm.nih. gov/pmc/articles/PMC3684593/

36. Spellberg B, Edwards J, Ibrahim A. Novel perspectives on mucormycosis: pathophysiology, presentation, and management. Clin Microbiol Rev. 2005;18:556-69.

37. Watkins TN, Gebremariam T, Swidergall M, Shetty AC, Graf KT, Alqarihi A, et al. Inhibition of EGFR Signaling Protects from Mucormycosis. mBio. 2018; Doi: https://doi. org/10.1128/mBio.01384-18

38. Alqarihi A, Gebremariam T, Gu Y, Swidergall M, Alkhazraji S, Soliman SSM, et al. GRP78 and Integrins Play Different Roles in Host Cell Invasion during Mucormycosis. mBio. 2020;11:e01087-20.

39. Bouchara JP, Oumeziane NA, Lissitzky JC, Larcher G, Tronchin G, Chabasse D. Attachment of spores of the human pathogenic fungus Rhizopus oryzae to extracellular matrix components. Eur J Cell Biol. 1996;70:76-83.

40. Liu M, Spellberg B, Phan QT, Fu Y, Fu Y, Lee AS, et al. The endothelial cell receptor GRP78 is required for mucormycosis pathogenesis in diabetic mice. J Clin Invest. 2010;120:1914-24.

41. Ibrahim AS, Spellberg B, Avanessian V, Fu Y, Edwards JE. Rhizopus oryzae Adheres to, Is Phagocytosed by, and Damages Endothelial Cells In Vitro. Infect Immun. 2005;73:778-83.

42. Baldin C, Ibrahim AS. Molecular mechanisms of mucormycosis-The bitter and the sweet. PLOS Pathog Public Library Sci. 2017;13:e1006408.

43. Ben-Ami R, Luna M, Lewis RE, Walsh TJ, Kontoyiannis DP. A clinicopathological study of pulmonary mucormycosis in cancer patients: Extensive angioinvasion but limited inflammatory response. J Infect. 2009;59:134-8.

44. Schulze B, Rambach G, Schwartze VU, Voigt K, Schubert $\mathrm{K}$, Speth C, et al. Ketoacidosis alone does not predispose to mucormycosis by Lichtheimia in a murine pulmonary infection model. Virulence. 2017;8:1657-67.

45. Svirshchevskaya EV, Shevchenko MA, Huet D, Femenia F, Latgé J-P, Boireau P, et al. Susceptibility of mice to invasive aspergillosis correlates with delayed cell influx into the lungs. Int J Immunogenet. 2009;36:289-99.

46. Radovanovic I, Mullick A, Gros P. Genetic Control of Susceptibility to Infection with Candida albicans in Mice. PLOS ONE. 2011;6:e18957.
47. Rhodes JC, Wicker LS, Urba WJ. Genetic Control of Susceptibility to Cryptococcus neoformans in Mice. Infect Immun. 1980;29:494-9.

48. Calich VL, Singer-Vermes LM, Siqueira AM, Burger E. Susceptibility and resistance of inbred mice to Paracoccidioides brasiliensis. Br J Exp Pathol. 1985;66:585-94.

49. Vilani-Moreno F, Fecchio D, de Mattos MC, MoscardiBacchi M, Defaveri J, Franco M. Study of pulmonary experimental paracoccidioidomycosis by analysis of bronchoalveolar lavage cells resistant vs susceptible mice. Mycopathologia. 1998;141:79-91.

50. Hasenclever HF. Comparative pathogenicity of Candida albicans for mice and rabbits. J Bacteriol. 1959;78:105-9.

51. Maheshwari RK, Tandon RN, Feuillette AR, Mahouy G, Badillet G, Friedman RM. Interferon inhibits Aspergillus fumigatus growth in mice: an activity against an extracellular infection. J Interferon Res. 1988;8:35-44.

52. van de Veerdonk FL, Netea MG. T-cell Subsets and Antifungal Host Defenses. Curr Fungal Infect Rep. 2010;4:238-43.

53. Mizui M. Natural and modified IL-2 for the treatment of cancer and autoimmune diseases. Clin Immunol Orlando Fla. 2018;206:63-70.

54. Tani EM, Franco M, Peraçoli MT, Montenegro MR. Experimental pulmonary paracoccidioidomycosis in the Syrian hamster: morphology and correlation of lesions with the immune response. J Med Vet Mycol Bi-Mon Publ Int Soc Hum Anim Mycol. 1987;25:291-300.

55. Lin L, Ibrahim AS, Xu X, Farber JM, Avanesian V, Baquir B, et al. Th1-Th17 Cells Mediate Protective Adaptive Immunity against Staphylococcus aureus and Candida albicans Infection in Mice. PLoS Pathog [Internet]. 2009 [cited 2020 Mar 17];5. Available from: https://www.ncbi. nlm.nih.gov/pmc/articles/PMC2792038/

56. Uezu K, Kawakami K, Miyagi K, Kinjo Y, Kinjo T, Ishikawa $\mathrm{H}$, et al. Accumulation of $\gamma \delta \mathrm{T}$ Cells in the Lungs and Their Regulatory Roles in Th1 Response and Host Defense against Pulmonary Infection with Cryptococcus neoformans. J Immunol Am Assoc Immunol. 2004;172:7629-34.

57. Lortholary O, Improvisi L, Fitting C, Cavaillon J-M, Dromer F. Influence of gender and age on course of infection and cytokine responses in mice with disseminated Cryptococcus neoformans infection. Clin Microbiol Infect Elsevier. 2002;8:31-7.

58. Bacher P, Kniemeyer O, Schönbrunn A, Sawitzki B, Assenmacher M, Rietschel E, et al. Antigen-specific expansion of human regulatory $\mathrm{T}$ cells as a major tolerance mechanism against mucosal fungi. Mucosal Immunol. 2014;7:916-28.

59. Jolink H, Hagedoorn RS, Lagendijk EL, Drijfhout JW, van Dissel JT, Falkenburg JHF, et al. Induction of A fumigatusspecific CD4-positive $\mathrm{T}$ cells in patients recovering from invasive aspergillosis. Haematologica. 2014;99:1255-63.

60. Bedke T, Iannitti RG, De Luca A, Giovannini G, Fallarino F, Berges C, et al. Distinct and complementary roles for Aspergillus fumigatus-specific $\operatorname{Tr} 1$ and Foxp3+ regulatory $\mathrm{T}$ cells in humans and mice. Immunol Cell Biol. 2014;92:659-70.

61. Cenci E, Mencacci A, Bacci A, Bistoni F, Kurup VP, Romani L. T cell vaccination in mice with invasive 
pulmonary aspergillosis. $\mathrm{J}$ Immunol Baltim $\mathrm{Md}$. 1950;2000(165):381-8.

62. E C, A M, C F d'Ostiani, G DS, P M, C M, et al. CytokineAnd T Helper-Dependent Lung Mucosal Immunity in Mice With Invasive Pulmonary Aspergillosis [Internet]. J. Infect. Dis. J Infect Dis; 1998 [cited 2020 Mar 26]. Available from: https://pubmed.ncbi.nlm.nih.gov/9815229/

63. Gresnigt MS, Bozza S, Becker KL, Joosten LAB, Abdollahi-Roodsaz S, van der Berg WB, et al. A polysaccharide virulence factor from Aspergillus fumigatus elicits anti-inflammatory effects through induction of Interleukin-1 receptor antagonist. PLoS Pathog. 2014;10:e1003936.

64. Fontaine T, Delangle A, Simenel C, Coddeville B, van Vliet SJ, van Kooyk Y, et al. Galactosaminogalactan, a new immunosuppressive polysaccharide of Aspergillus fumigatus. PLoS Pathog. 2011;7:e1002372.

65. Chai LYA, van de Veerdonk F, Marijnissen RJ, Cheng S-C, Khoo AL, Hectors M, et al. Anti-Aspergillus human host defence relies on type $1 \mathrm{~T}$ helper (Th1), rather than type $17 \mathrm{~T}$ helper (Th17), cellular immunity. Immunology. 2010;130:46-54.

66. Zelante T, De Luca A, Bonifazi P, Montagnoli C, Bozza S, Moretti S, et al. IL-23 and the Th17 pathway promote inflammation and impair antifungal immune resistance. Eur J Immunol. 2007;37:2695-706.

67. Romani L, Zelante T, De Luca A, Fallarino F, Puccetti P. IL-17 and therapeutic kynurenines in pathogenic inflammation to fungi. J Immunol Baltim Md. 1950;2008(180):5157-62.

68. Lindén A, Laan M, Anderson GP. Neutrophils, interleukin17A and lung disease. Eur Respir J. 2005;25:159-72.

69. Damsker JM, Hansen AM, Caspi RR. Th1 and Th17 cells: adversaries and collaborators. Ann N Y Acad Sci. 2010;1183:211-21.

70. Antachopoulos C, Roilides E. Cytokines and fungal infections. Br J Haematol. 2005;129:583-96.
71. Nagai H, Guo J, Choi H, Kurup V. Interferon-gamma and tumor necrosis factor-alpha protect mice from invasive aspergillosis. J Infect Dis. 1995;172:1554-60.

72. Muraille E, Leo O, Moser M. Th1/Th2 Paradigm Extended: Macrophage Polarization as an Unappreciated PathogenDriven Escape Mechanism? Front Immunol [Internet]. Frontiers; 2014 [cited 2021 Jul 20];0. Available from: https://www.frontiersin.org/articles/https://doi.org/10. 3389/fimmu.2014.00603/full

73. Salim T, Sershen CL, May EE. Investigating the Role of TNF- $\alpha$ and IFN- $\gamma$ Activation on the Dynamics of iNOS Gene Expression in LPS Stimulated Macrophages. PLoS ONE. 2016;11:e0153289.

74. Simitsopoulou M, Roilides E, Maloukou A, Gil-Lamaignere C, Walsh TJ. Interaction of amphotericin B lipid formulations and triazoles with human polymorphonuclear leucocytes for antifungal activity against Zygomycetes. Mycoses. 2008;51:147-54.

75. Gil-Lamaignere C, Simitsopoulou M, Roilides E, Maloukou A, Winn RM, Walsh TJ. Interferon- gamma and granulocyte-macrophage colony-stimulating factor augment the activity of polymorphonuclear leukocytes against medically important zygomycetes. J Infect Dis. 2005;191:1180-7.

76. Park SJ, Hughes MA, Burdick M, Strieter RM, Mehrad B. Early NK cell-derived IFN-\{gamma $\}$ is essential to host defense in neutropenic invasive aspergillosis. J Immunol Baltim Md. 1950;2009(182):4306-12.

77. Schmidt S, Tramsen L, Perkhofer S, Lass-Flörl C, Hanisch $\mathrm{M}$, Röger F, et al. Rhizopus oryzae hyphae are damaged by human natural killer (NK) cells, but suppress NK cell mediated immunity. Immunobiology. 2013;218:939-44.

Publisher's Note Springer Nature remains neutral with regard to jurisdictional claims in published maps and institutional affiliations. 